\title{
Adhesive small bowel obstruction: predictive value of oral contrast administration on the need for surgery
}

\author{
J. Perea García, F. Turégano Fuentes, B. Quijada García, A. Trujillo, P. Cereceda, B. Díaz Zorita, D. Pérez \\ Díaz and M. Sanz Sánchez
}

Emergency Department. Surgical Section. Universitary General Hospital Gregorio Marañón. Madrid, Spain

\begin{abstract}
Introduction: adhesive small bowel obstruction (SBO) is a common cause of hospital admission. Nonoperative management is initially recommended unless there is suspicion of strangulation, but its optimal duration is controversial. The aims of our study was to evaluate the usefulness of radiographic small bowel examination with contrast medium to predict the need for surgery in SBO.

Material and methods: this prospective study carried out from January 1999 to December 2001, included 100 patients with clinical and radiological criteria of adhesive SBO. We described the past medical history, as well as clinical picture, blood tests and radiological findings in these patients. Fifty cubic centimeters of $5 \%$ barium suspension were given orally, and plain abdominal radiographs were taken at $4,8,16$, and 24 hours afterwards. A liquid diet was given as soon as the contrast medium appeared in the right colon. Otherwise, surgical intervention was considered based on the outcome of the patient and the criteria of the emergency surgical team.
\end{abstract}

Results: in 70 patients, barium contrast appeared in the right colon, and a liquid diet was tolerated by 69 of them $(98.6 \%)$. Mean hospitalization time for this group was $43 \pm 17$ hours. In the remaining 30 patients, no evidence of barium contrast in the right colon was seen, and 25 of them underwent surgery (75\%), while the other 5 tolerated a liquid diet. Mean hospitalization time for this second group of patients was 13.8 \pm 11 days. Sensitivity, specificity, positive predictive value, and negative predictive value for the absence of contrast medium in the right colon within 24 hours as a predictor of surgery were 93, 96, 98 and 83\%, respectively. There was a statistical significant relationship $(p<0.01)$ between the "Presence of contrast medium in the right colon" and "Oral diet tolerance". Only the variable "Number of previous surgical interventions" tended to reach statistical significance $(p=0.07)$. Tolerance of liquid diet was more likely when patients had more than one previous abdominal surgery.

Conclusions: early oral administration of a radiological contrast medium in patients with adhesive SBO can effectively predict the need for a surgical procedure. It can shorten not only hospital

Recibido: 24-07-03.

Aceptado: 14-10-03.

Correspondencia: José Perea García. C/ Meléndez Valdés, 54, 4 C. 28015 Madrid. Telf.: 915498994. stay, but also the potential morbidity of late surgery, secondary to a prolonged and unsuccessful nonoperative treatment.

Key words: Small bowel obstruction. Adhesive syndrome. Radiological contrast. Surgery.

Perea García J, Turégano Fuentes F, Quijada García B, Trujillo A, Cereceda P, Díaz Zorita B, Pérez Díaz D, Sanz Sánchez M. Adhesive small bowel obstruction: predictive value of oral contrast administration on the need for surgery. Rev Esp Enferm Dig 2004; 96: 191-200.

\section{INTRODUCTION}

Adhesive small bowel obstruction (SBO) is a common cause of hospital admission. Clinical evolution is unpredictable and its management is controversial. Surgery is immediately performed when there are signs and symptoms suggesting intestinal strangulation (1); otherwise, and in most cases, initial treatment must be nonoperative $(2,3)$. However, the duration of this treatment remains controversial (from 12 hours to 5 days) $(2,4-6)$, and, from a clinico-radiographic point of view, it is very difficult to predict initially which patients will ultimately need an operation. In our hospital many patients undergo surgery after 72 hours or more of nonoperative treatment, which potentially may contribute to increase the morbidity of these patients. Moreover, there are cases of spontaneous resolution after 4 to 5 days of nonoperative management, and surgery may be avoided in these patients.

This potential use of a radiological contrast has been recently evaluated. It has been suggested that its appearance in the cecum would be indicative of spontaneous re- 
solution of the obstruction. Otherwise, the need for a surgical intervention is predicted (5,7-9). There is also a possible therapeutic effect of water-soluble contrast media (Gastrografin ${ }^{\mathrm{TM}}$ : sodium diatrizoate, meglumide ditrizoate, humidifying agent) on obstruction resolution (6,7,10-12).

We describe a prospective trial of patients who presented with adhesive SBO, to whom a radiological contrast medium was given early, with the objective of assessing its use in predicting the need for surgery, the mean hospital stay, and the potential morbidity of a surgical procedure.

\section{MATERIAL AND METHODS}

\section{Study design and selection of patients}

An evaluation study for a diagnostic method defined as Radiological Contrast Trial to establish need of surgery, in patients admitted to our Emergency Department from January 1999 to December 2001 with clinical and radiological features of adhesive SBO (Fig. 1). Exclusion criteria included patients with clinical evidence of intestinal strangulation and those who developed SBO within 30 days after surgery.

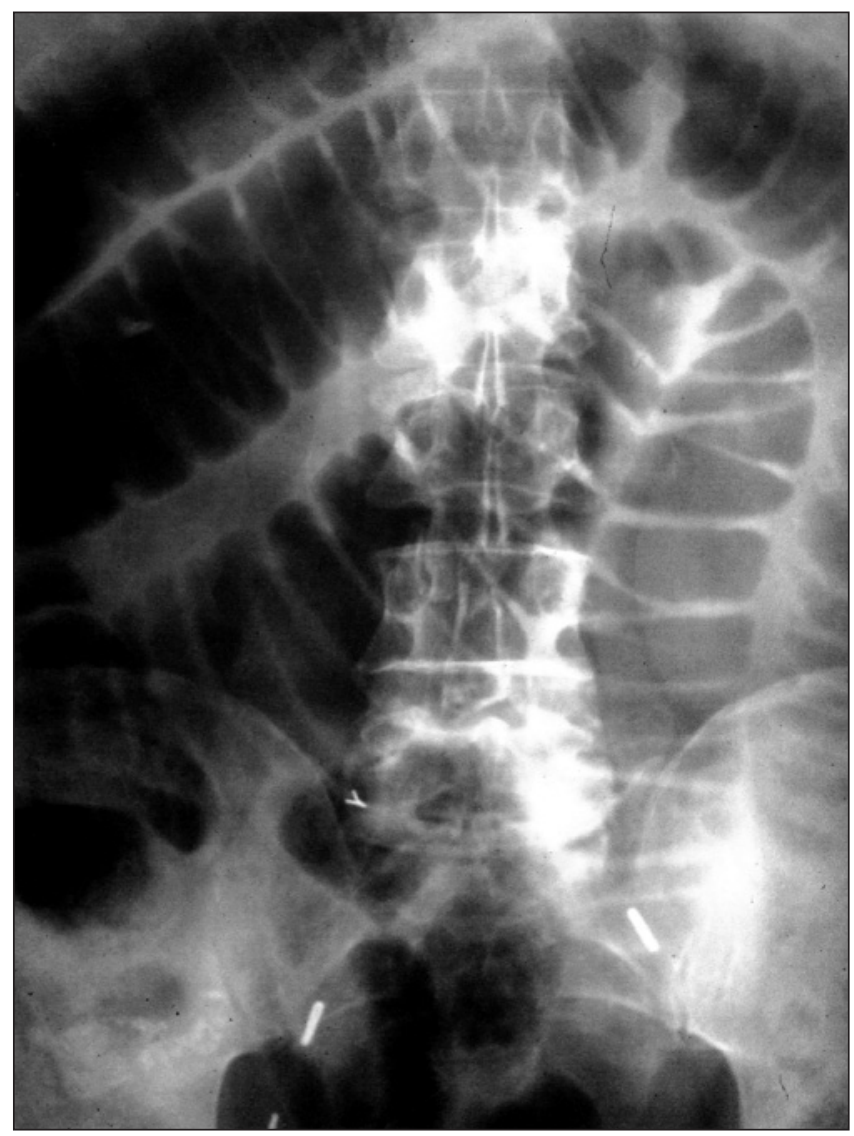

Fig. 1.- Plain abdominal radiograph. Partial small bowel obstruction. Radiografía simple de abdomen. Obstrucción intestinal parcial.

\section{Technique}

Once a clinical and radiological diagnosis of adhesive SBO was made, patients were managed with intravenous fluids and a nasogastric tube for 2 hours. No analgesic treatment was given. Then, $50 \mathrm{cc}$ of $5 \%$ diluted barium suspension were given orally or through the nasogastric tube, which was clamped thereafter.

Abdominal radiographs were taken at 4, 8, 16 and 24 hours afterwards. As soon as barium appeared in the right colon (Fig. 2) oral liquids were given. Otherwise, an indication of surgery was established based on clinical and radiological outcome and the decision of the attending surgeon. Patients with increased abdominal pain at any time underwent laparotomy and were excluded from the study. We used barium suspension instead of Gastrografin ${ }^{\mathrm{TM}}$, since our preliminary study with this water-soluble contrast medium did not allow a proper view of the gastrointestinal tract in most cases. The concentration of barium was chosen by our radiologists, and was low enough to prevent complications in case of surgery.

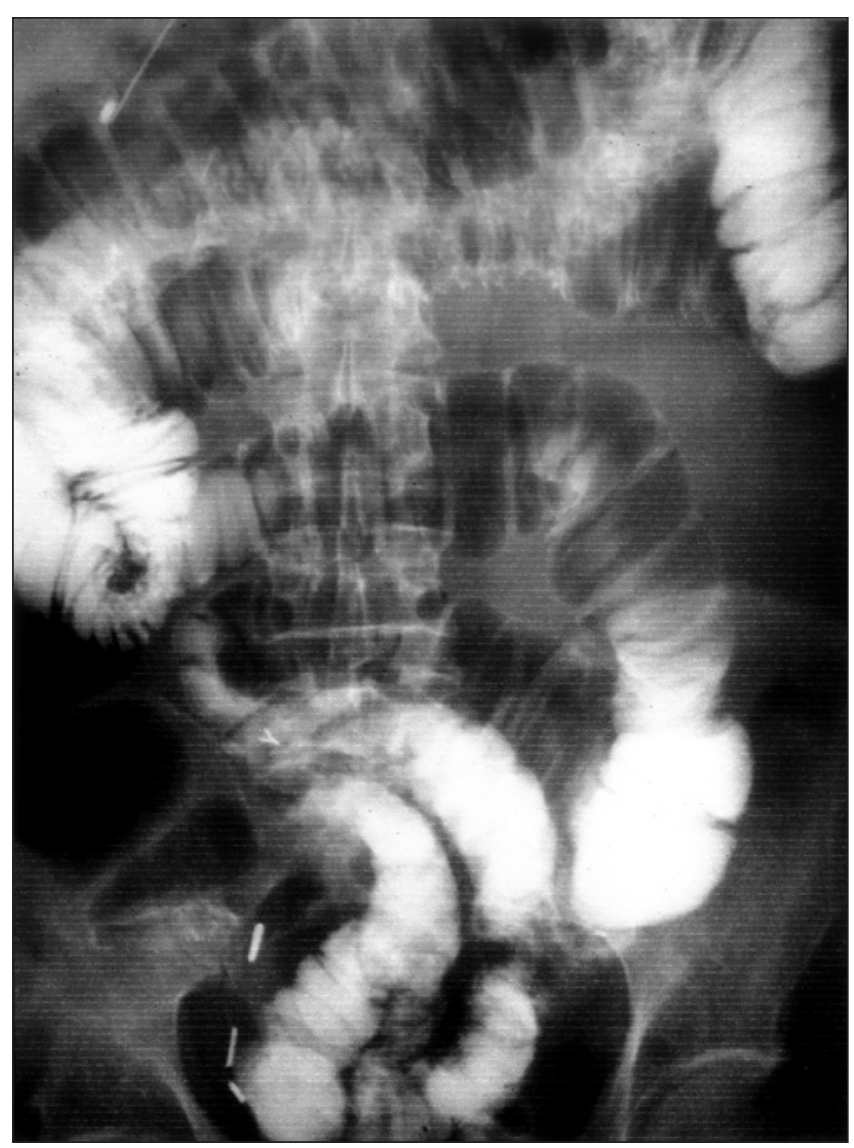

Fig. 2.- Abdominal radiograph after administration of a barium contrast medium showing its distribution thorough the small and large bowel. Radiografía de abdomen tras la administración del contraste baritado. Se aprecia distribución del mismo tanto en intestino delgado como en colon. 


\section{Variables}

Primary variable: effective tolerance of a liquid diet in the absence of vomiting, nausea, or abdominal pain. Secondary variables: Age, sex, previous abdominal surgery, previous hospitalizations because of SBO, clinical features, complementary data (fever, tachycardia, leukocytosis), plain abdominal radiographs at admission (partial or complete obstruction, depending on the presence or absence of gas within the distal colon). Possible complications because of contrast administration were assessed, as well as intraoperative findings, surgical technique, postoperative complications, and mean hospital stay.

\section{Statistical analysis}

Data were included in a data base and analyzed with the statistical software program SPSS (v 9.0 for Windows). Confidence intervals (95\%) for sensitivity, specificity, positive and negative predictive value, and overall test value were calculated with the EPIDAT program, version 2.1. Data are given using frequency values (absolute and proportions) for categorical variables, and mean, standard deviation and range values for quantitative measurements. The diagnostic test was evaluated using sensitivity, specificity, predictive values, and overall efficiency, with their respective confidence intervals (95\% ICs). Looking for a variable related to effective tolerance, Student's t test was used for quantitative variables, and a Chi-square test (or its non-parametric equivalent: Fi-sher's test) in case of dicotomic variables. A $p<0.05$ was considered significant.

\section{RESULTS}

Male to female ratio was 44/56, with a mean age of 64 years (range: 23-100). Previous abdominal surgery and stays due to adhesive SBO, as well as clinical outcome, are shown in tables I and II. They all had at least one previous abdominal operation, only one in most cases (67 cases), with a mean of 1.4 previous operations, and a median time between present admission and last abdominal surgery of 5.5 years.

All 100 patients were included in the trial, with a mean time from admission to our Emergency Department to barium administration of 16 hours. Seventy patients had contrast medium in the right colon at a median 8 hours since administration, and an effective liquid diet was tolerated by 69 of them. The remaining patient underwent surgery 48 hours after admission, and an internal hernia was found during laparotomy. None of them experienced complications related to contrast medium administration. The 69 patients who tolerated liquid diet had a clinical and radiological resolution of SBO at $43 \pm 17$ hours after
Table I. Clinical history of patients

\begin{tabular}{cc}
\hline No. of previous abdominal surgeries: & $\mathrm{n}=100$ \\
1 & 67 \\
2 & 22 \\
3 & 8 \\
4 & 3 \\
& \\
Type of previous abdominal surgery*: & $\mathrm{n}=100$ \\
1. Colon \& rectum & 20 \\
2. Gynecologic & 18 \\
3. Appendectomy & 17 \\
4. Gastric & 15 \\
5. Bile tract & 11 \\
6. Other & 19
\end{tabular}

Previous admissions because of adhesive SBO (Yes / No) 29 / 71

Mean time since last admission (range)

2 years $(0.5-40)$

Surgery in previous admissions (Yes / No)

$6 / 23(20 \% / 80 \%)$

Type of surgery in previous admission

$\begin{array}{ll}\text { 1. Adhesiotomy } & 4 \\ \text { 2. Bowel resection } & 2\end{array}$

*First surgery is only considered for all patients.

Table II. Clinical features

\begin{tabular}{lr}
\hline Clinical features & \\
Vomiting & 77 \\
Constipation & 52 \\
Mild or moderate abdominal pain (colic / constant) & $68 / 12$ \\
Site of pain (localized / diffuse) & $46 / 34$ \\
Abdominal distension & 56 \\
& \\
Mean evolution time ( \pm standard deviation) & $2.1 \pm 2$ days \\
Complementary data* & \\
Fever & \\
Leukocytosis & \\
Tachycardia (HF)** & \\
Radiology at admission & \\
Partial obstruction & \\
Complete obstruction & \\
*(Mean in case of "Yes" \pm standard deviation) & \\
$* *$ HF: Heart frequency in beats per minute & 25 \\
\hline
\end{tabular}

admission to the Emergency Department and were discharged from hospital.

The remaining 30 patients had no contrast medium in the right colon in none of the abdominal radiographs, although the medium appeared in the small bowel in 15 of them (50\%). In 25 of these 30 patients, surgery was performed because of lack of improvement at a mean 43 hours after admission (minimum: 6 hours; maximum: 72 hours); meanwhile, the remaining 5 patients were put on a liquid diet because of clinical improvement. The minimum time of 6 hours occurred in a patient who had 


\section{Table III. Surgical findings and techniques}

\begin{tabular}{lr}
\hline Surgical findings & $n=25$ \\
Isolated adhesive obstruction & 11 \\
Internal hernia & 9 \\
Intestinal torsion & 3 \\
Neoplasm & 1 \\
Intestinal ischemia & 1 \\
Intestinal strangulation & 8 \\
& \\
Surgical techniques & \\
Adhesiotomy & 21 \\
Intestinal resection & 8 \\
Reduction of volvulus & 3 \\
Ostomy & 1 \\
Laparotomy & 1
\end{tabular}

markedly increased abdominal pain and underwent surgery without ever completing the trial. Findings and surgical techniques are described in table III. No cases of perforation with barium spillage in the peritoneal cavity were found, and the presence of barium did not increase the difficulty of small bowel resection. One patient who had small bowel ischemia of thrombotic origin was originally misdiagnosed of SBO. Five patients developed postoperative complications (20\%), including three wound infections, one urinary tract infection, and one ileus. One patient died at day 4 after surgery because of congestive heart failure (postoperative mortality was $4 \%$, and $1 \%$ overall in the series).

Mean hospitalization time was $13.8 \pm 11$ days (range: 5-55 days) for the 30 patients without evidence of contrast medium in the right colon.

Of the 25 patients with initial radiological evidence of complete obstruction, 17 were treated nonoperatively (68\%) and 8 underwent operative management on (32\%). Of the 75 patients with partial obstruction, 58 were treated nonoperatively (77\%) and 17 were managed surgically (23\%).

Sensitivity, specificity, positive and negative predictive values, and overall test value, of the absence of contrast medium in the right colon within 24 hours as being predictive of the need for surgery, were $93,96,98,83$ and

Table IV. Absence of contrast medium in the right colon as predictive for the need for surgery

\begin{tabular}{lcc}
\hline Diagnostic indexes & & $\begin{array}{c}\text { 95\% Confidence intervals } \\
\text { (lower-upper) }\end{array}$ \\
\hline Sensibility & $93.24 \%$ & $(84.27-97.49)$ \\
Specificity & $96.15 \%$ & $(78.41-99.80)$ \\
Positive predictive value & $98.57 \%$ & $(91.23-99.23)$ \\
Negative predictive value & $83.33 \%$ & $(64.54-93.70)$ \\
Global value of the test & $94 \%$ & $(86.88-97.54)$ \\
\hline
\end{tabular}

94\%, respectively (Table IV). In 15 patients no contrast appeared in any abdominal radiographs, and all of them underwent surgery because of lack of clinical and radiological improvement.

There was a statistical significant relationship between the presence of contrast medium in the right colon and the effective liquid tolerance. Likewise, absence of contrast in the right colon was associated with the need for surgery $(\mathrm{p}<0.01)$. Only the variable "number of previous operations" tended toward statistical significance $(p=0.07)$. Thus, a positive oral tolerance was more likely if the patient had more than one previous abdominal surgery (pooled variable: "effective tolerance").

\section{DISCUSSION}

Adhesive SBO is a common surgical emergency whose global management still remains controversial. Although in the absence of signs of strangulation nonoperative management is usually indicated, the duration of this treatment is very variable. Most authors recommend that this period of nonoperative treatment should not exceed 48 hours $(6,13,14)$, although clinical evidence exists for spontaneous resolution after 4 or 5 days.

Demographic and clinical data of our patients are similar to those in other series, except the evidence of previous admissions for $\mathrm{SBO}$, which was two times that of a recent report (15).

Only a few patients with adhesive SBO complain of severe abdominal pain, and the severity of such pain is a most important element for surgical decision. The presence of severe and continuous pain, with or without other signs, must make one suspect strangulation and indicate an emergency laparotomy. Nevertheless, a majority of patients will have a benign clinical presentation with abdominal distension and absent or mild pain.

Rates of operation in adhesive SBO vary between 27 and $42 \%$ (25\% in our series). The fact that previous abdominal surgery of the inframesocolic compartment increases this rate is well known (2,15-17).

There are series in which predictive factors are used to help choose the best treatment in each case. Escrig et al. showed that absence of gas in the large bowel, electrolyte disorders, and inframesocolic location of previous surgery had all an independent predictive value for surgical intervention (15). In our series, only the larger numbers of previous operations seem to negatively predict the need for surgery. A complete radiological obstruction at the beginning, defined as an absence of gas in the colon, was neither predictive of absence of contrast medium in the colon, nor of possible indication for surgery. Of those who had contrast in the colon, $22 \%$ had initially a complete radiological obstruction, whereas $32 \%$ of those without contrast medium in the colon had a radiological obstruction. In our series, plain abdominal radiographs of complete SBO were not predictive of surgical management. Other- 
wise, the diagnostic approach we propose in this study would have been not necessary. Other authors have shown that the amount of nasogastric tube drainage, as well as the grade of dilatation of the small bowel loops, is predictive of surgical management (7). Nevertheless, it should be emphasized that clear risk factors for the failure of nonoperative treatment of this condition have yet to be identified.

The use of a water-soluble contrast medium has been recently evaluated with the aim of predicting the need for surgical intervention in SBO. The possible therapeutic role of this contrast medium still remains controversial. In a randomized study, Assalia et al. suggested that Gastrografin ${ }^{\mathrm{TM}}$ administration shortened hospital stay and the need for surgery by $10 \%$ (6). On the other hand, Feigin et al., and Fevang et al. found no such advantages $(11,12)$.

Chen et al. studied the predictive value of this type of water-soluble contrast in the management of adhesive SBO (5). They showed that patients with contrast in the right colon within 24 hours were all successfully managed with a nonoperative treatment. Laparotomy was necessary in $96 \%$ of patients who had no contrast in the right colon within 24 hours. Our study confirms the results obtained by Chen et al., but using a diluted barium suspension (5). Nevertheless, our negative predictive value was lower, as a number of patients without contrast in the right colon did not need any surgery.

A barium contrast concentration of $5 \%$, as determined by the Radiology Department, theoretically prevented the risk of complications. This was calculated as the minimum concentration needed to allow a proper view of contrast in the bowel lumen. However, the use of a barium suspension avoided the osmotic properties of Gas$\operatorname{trographin}^{\mathrm{TM}}$, which may play a role in the spontaneous resolution of the SBO. An important aspect in our results is the total absence of contrast -in either the small or large bowel- in the plain abdominal radiographs of 15 patients. All of them underwent surgery because of lack of clinical improvement. We believe that a most probable explanation is that the absence of contrast was due to severe loop distension, with subsequent fluid and air accumulation and contrast dilution. It is reasonable to conclude that clinical improvement after nonoperative treatment is unlikely with such an extensive obstruction.

Hospital stay was shortened by this diagnostic approach to patients who finally did not require surgery, and our data show a mean stay at the Emergency Department of $43 \pm 17$ hours. Recent series report a mean stay of 6 days for those who received nonoperative treatment, very similar to that of patients who underwent surgery (15). If our results are confirmed by other groups, this protocol could reduce the time to laparotomy and also the duration of nonoperative management for adhesive SBO. Shorter duration of nonoperative management, and earlier surgery could as well reduce the rate of intestinal resections and their subsequent morbidity.
In conclusion, the early use of a radiological contrast (diluted barium suspension) in patients with adhesive SBO can predict the need for surgery in an earlier and more efficient way, with a subsequent reduction in the hospitalization time and potential late-surgery morbidity.

\section{ACKNOWLEDGEMENTS}

We are grateful to the Research Unit of our Institution for their collaboration in the statistical analysis of the data.

\section{REFERENCES}

1. Playforth RH, Holloway JB, Griffin WO. Mechanical small bowel obstruction: a plea for early surgical intervention. Ann Surg 1970; 171: 783-8.

2. Seror D, Feigin E, Szold A, Allweiss TM, Carmon M, Nissan S. How conservative can postoperative small bowel obstruction be treated? Am J Surg 1993; 165: 121-6.

3. Tanphiphat C, Chittmittrapap S, Prasopsunti K. Adhesive small bowel obstruction. A review of 321 cases in Thai hospital. Am J Surg 1987; 154: 283-7.

4. Brolin RE. Partial small bowel obstruction. Surgery 1984; 95: 145-9.

5. Chen SC, Lin FY, Lee PH, Yu SC, Wang SM, Chang KJ. Water-soluble contrast study predicts the need for early surgery in adhesive small bowel obstruction. Br J Surg 1998; 85: 1692-4.

6. Assalia A, Schein M, Kopelman D, Hirshberg A, Hashmonai M. Therapeutic effect of oral Gastrografin in adhesive, partial small bowel obstruction: A prospective randomized trial. Surgery 1994; 115: 433 7.

7. Choi HK, Chu KW, Law WL. Therapeutic value of gastrografin in adhesive small bowel obstruction after unsuccessful conservative treatment. Ann Surg 2002; 236: 1-6.

8. Blackmon S, Lucius C, Wilson JP. The use of water-soluble contrast in evaluating clinically equivocal small bowel obstruction. Ann Surg 2000; 66: 238-44.

9. Chen SC, Chang KJ, Lee PH. Oral Urografin in postoperative small bowel obstruction. World J Surg 1999; 23: 1051-4.

10. Assalia A, Kopelman D, Bahous H. Gastrografin for mechanical, partial, small bowel obstruction due to adhesions. Harefuah 1997; 132: 629-33.

11. Feigin E, Seror D, Szold A. Water soluble contrast material has no therapeutic effect on postoperative small-bowel obstruction: Results of a prospective randomized clinical trial. Am J Surg 1996; 171: 227 9.

12. Fevang BT, Jensen D, Fevang J. Upper gastrointestinal contrast study in the management of small bowel obstruction -a prospective randomized study. Eur J Surg 2000; 166: 39-43.

13. Cox MR, Gunn IF, Eastman MC. The safety and duration of non-operative treatment for adhesive small bowel obstruction. Aust NZ J Surg 1993; 63: 367-71.

14. Sosa J, Gardner B. Management of patients diagnosed as acute intestinal obstruction secondary to adhesions. Am Surg 1993; 59: 125-8.

15. Escrig VJ, Ángel V, Senent V, Villegas C, Senis L, Salvador JL. Oclusión adherencial de intestino delgado: valores predictivos de la indicación quirúrgica. Cir Esp 2002; 72: 72-8.

16. Cox MR, Gunn IF, Eastman MC. The operative etiology and types of adhesions causing small bowel obstruction. Aust NZ J Surg 1993; 63: 848-52.

17. Matter I, Khalemsky L, Abrahamson J. Does the index operation influence the course and outcome of adhesive intestinal obstruction? Eur J Surg 1997; 163: 767-72. 


\title{
Obstrucción intestinal adherencial: valor predictivo de la administración precoz de contraste radiológico sobre la necesidad de cirugía
}

\author{
J. Perea García, F. Turégano Fuentes, B. Quijada García, A. Trujillo, P. Cereceda, B. Díaz Zorita, D. Pérez \\ Díaz y M. Sanz Sánchez
}

Departamento de Urgencias. Sección de Cirugía. Hospital General Universitario Gregorio Marañón. Madrid

\section{RESUMEN}

Introducción: la obstrucción intestinal adherencial (OIA) es una importante causa de ingreso hospitalario. Salvo que exista sospecha de estrangulación, está indicado inicialmente el manejo conservador. No obstante, el periodo óptimo de este permanece controvertido. Nuestro objetivo ha sido evaluar la utilidad del contraste radiológico en los cuadros de OIA como factor predictivo de la necesidad de cirugía.

Material y métodos: estudio prospectivo desde enero de 1999 a diciembre de 2001, de 100 pacientes con criterios clínico-radiológicos de OIA. Se describen los datos epidemiológicos, antecedentes personales de los pacientes, así como las características clínicas, analíticas y radiológicas del cuadro actual. Se les administraba $50 \mathrm{cc}$ de contraste baritado diluido al 5\%, realizándose radiografía de abdomen a las $4,8,16$ y 24 horas. Si en cualquiera de ellas aparecía el contraste en colon derecho se iniciaba la tolerancia a líquidos. En caso contrario, se determinaba la necesidad de cirugía en función de la evolución del paciente y a criterio del equipo quirúrgico de guardia. Se analiza estadísticamente la capacidad del protocolo de predecir la necesidad de cirugía en estos pacientes, así como el análisis para identificar alguna variable que sea útil para predecir la positividad de la prueba. La base de datos ha sido elaborada con el paquete SPSS 9.0.

Resultados: setenta pacientes presentaron contraste baritado en colon derecho, siendo efectiva la tolerancia oral en 69 de ellos $(98,6 \%)$. La media de estancia hospitalaria fue de $43 \pm 17$ horas. En los 30 restantes no se objetivó contraste en colon derecho. De estos, a 25 se les indicó cirugía (75\%) en los días siguientes, mientras que en 5 la tolerancia a líquidos resultó efectiva. El tiempo medio de estancia fue de 13,8 \pm 11 días. La sensibilidad, especificidad, valor predictivo positivo y valor predictivo negativo de la ausencia de contraste en colon derecho en las primeras 24 horas como indicador de cirugía fue respectivamente de $93,96,98$ y $83 \%$. Existe significación estadística, para una $p<0,01$, entre la variable "contraste en colon derecho" y la variable "tolerancia efectiva". En la identificación de alguna variable predictora de la positividad de la prueba, sólo el "número de cirugías previas" tiende a la significación estadística para una $p=0,07$, siendo más probable la tolerancia si el paciente presentaba más de una cirugía abdominal previa (variable de agrupación: "tolerancia efectiva").

Conclusiones: la administración oral precoz de contraste radiológico en pacientes con OIA puede predecir de forma eficaz la necesidad de cirugía. Permite reducir no sólo la estancia hospitalaria, sino la morbilidad potencial de una cirugía tardía generada por la prolongación en el tiempo de un tratamiento conservador ineficaz.

Palabras clave: Obstrucción intestinal. Síndrome adherencial. Contraste radiológico. Cirugía.

\section{INTRODUCCIÓN}

La obstrucción intestinal adherencial (OIA) es una importante causa de ingreso hospitalario. El curso clínico de la misma es imprevisible, siendo su manejo controvertido. La cirugía está indicada de forma inmediata cuando existe sospecha de estrangulación (1), mientras que en una mayoría de casos el tratamiento inicial debe ser conservador $(2,3)$. Sin embargo, el periodo óptimo del mismo es controvertido (desde 12 horas hasta 5 días) (2,4-6), siendo muy difícil predecir en muchos casos, al comienzo del cuadro y desde el punto de vista clínico-radiológico, qué pacientes van a necesitar cirugía. En nuestro medio muchos pacientes se operan después de 72 horas o más de tratamiento conservador, con lo que ello conlleva de aumento de la morbilidad potencial. Así mismo, existen casos de resolución espontánea tras 4 ó 5 días de tratamiento conservador, evitándose en estos pacientes la cirugía.

El papel del contraste radiológico ha sido evaluado recientemente, habiéndose publicado que el paso precoz del contraste al ciego sería indicativo de la resolución espontánea del cuadro obstructivo, siendo por tanto de valor diagnóstico en la medida en que indicaría en caso contrario la necesidad de cirugía (5,7-9). Se añade, además, el posible efecto terapéutico del contraste hidrosoluble (Gastrografín ${ }^{\mathrm{TM}}$ : diatrizoato sódico, diatrizoato de meglumina, junto con un agente humidificador) en la resolución del cuadro $(6,7,10-12)$.

Presentamos una serie prospectiva de pacientes que presentaron cuadro de OIA a los que se administra precozmente contraste radiológico, con el objetivo de evaluar su utilidad predictiva de la necesidad de cirugía y consecuente disminución de la estancia media y la morbilidad potencial de una cirugía tardía.

\section{MATERIAL Y MÉTODOS}

\section{Diseño del estudio y selección de pacientes}

Estudio de evaluación de una prueba diagnóstica definida como protocolo de contraste radiológico, para deter- 
minar la necesidad de cirugía, realizado en pacientes que ingresaron desde enero de 1999 a diciembre de 2001 en el Departamento de Urgencias de nuestro centro, con cuadro clínico-radiológico de OIA (Fig. 1). Han sido excluidos los pacientes con evidencia clínica inicial de estrangulación, y aquellos con obstrucción dentro de los 30 primeros días postoperatorios.

\section{Técnica}

Una vez determinado el diagnóstico clínico-radiológico de OIA, el paciente era tratado de manera inicial mediante fluidoterapia parenteral y colocación de sonda nasogástrica (SNG) durante dos horas. En ningún caso se pautaba analgesia. Posteriormente se les administraba $50 \mathrm{cc}$ de bario diluido al 5\%, por vía oral o por $\mathrm{SNG}$, con pinzamiento posterior de la misma.

A continuación se realizaban radiografías de abdomen a las 4, 8, 16 y 24 horas tras administración del contraste. Si en cualquiera de las radiografías aparecía contraste en el colon derecho (Fig. 2), se iniciaba tolerancia a líquidos. En caso contrario, se indicaba la necesidad de cirugía en función de la evolución clínico-radiológica del paciente, y a criterio del equipo quirúrgico de guardia. Si el pacientes experimentaba en cualquier momento un aumento claro del dolor abdominal se indicaba cirugía, sin esperar a completar el estudio radiológico.

El uso del contraste baritado en lugar del contraste hidrosoluble, más referido en la bibliografía, fue debido a que el empleo inicial de este no permitió una buena visualización del mismo en el tubo digestivo, incluso desde la primera radiografía realizada, en una mayoría de los casos en los que se utilizó. Previa consulta con el Departamento de Radiología, se decidió la utilización de contraste baritado a una concentración que se estimó como lo suficientemente baja como para no dar complicaciones en caso de intervención quirúrgica, y suficiente como para permitir su visualización.

\section{Variables}

Variable desenlace: tolerancia efectiva, siendo esta positiva en el caso en que tras probar ingesta de líquidos, no se producían vómitos, náuseas, ni dolor abdominal.

Resto de variables: se recogieron las siguientes: edad, sexo, cirugías abdominales previas, ingresos anteriores de cuadros obstructivos, manifestaciones clínicas, datos complementarios (fiebre, taquicardia, presencia de leucocitosis), radiología al ingreso (obstrucción parcial o completa, según presencia o ausencia de gas distal en el colon).

También se recogen las posibles complicaciones debidas a la administración de contraste, los hallazgos intraoperatorios, la técnica quirúrgica empleada, las complicaciones postoperatorias y la estancia media.

\section{Procesamiento de datos}

Los datos fueron incluidos en una base de datos y analizados con el programa estadístico SPSS (v 9.0 para Windows). Los intervalos de confianza para el $95 \%$ de los valores de sensibilidad, especificidad, valor predicitivo positivo y negativo, así como el valor global de la prueba han sido elaborados mediante el programa EPIDAT, Versión 2.1.

Se presentan los datos utilizando medidas de frecuencia (absolutas y porcentajes) para las variables categóricas, y media, desviación típica y rango para las medidas de forma cuantitativa. La prueba diagnóstica se ha evaluado con las medidas de sensibilidad, especificidad, valores predictivos y eficiencia global con sus respectivos intervalos de confianza (IC 95\%). Con la finalidad de explorar si existía alguna variable relacionada con la tolerancia efectiva se ha realizado la $t$ de Student para explorar variables cuantitativas y la Chi cuadrado (o su equivalente no paramétrico, prueba de Fisher) si eran dicotómicas. El nivel de significación elegido es de $\mathrm{p}<$ 0,05 .

\section{RESULTADOS}

De los 100 pacientes, 56 fueron mujeres y 44 hombres, con una edad media de 64 años (rango: 23-100). Los antecedentes de los pacientes en relación con cirugías abdominales previas e ingresos por cuadros obstructivos adherenciales, así como el cuadro clínico que presentaban en el ingreso actual se describen en las tablas I y II.

Todos presentaban como antecedentes al menos una cirugía abdominal previa, siendo una única lo más frecuente, en 67 casos, con una media de 1,4 cirugías previas, y una mediana de tiempo entre el ingreso actual y la última cirugía abdominal de 5,5 años.

Los 100 pacientes fueron incluidos en el protocolo, con un tiempo medio desde el ingreso en Urgencias hasta la administración de contraste de 16 horas. Setenta pacientes presentaron contraste en colon derecho, con una mediana de 8 horas desde la administración, siendo efectiva la tolerancia a líquidos en 69 de ellos. El único restante no toleró la dieta líquida, motivo por el cual se indicó la intervención quirúrgica a las 48 horas del ingreso, hallando en la laparotomía una hernia interna como causante del cuadro. Ninguno presentó complicaciones derivadas de la administración del contraste. Los 69 pacientes que toleraron bien la dieta líquida fueron dados de alta con resolución clínica y radiológica del cuadro a las $43 \pm$ 17 horas (media \pm desviación estándar) del ingreso en el Servicio de Urgencias.

En los 30 pacientes restantes no se evidenció contraste en colon derecho en ninguna de las radiografías realizadas, aunque sí se observó contraste en el intestino delgado en 15 (50\%) de ellos. De estos, en 25 se indicó cirugía por ausencia de mejoría del cuadro clínico a las 43 horas 
Tabla I. Antecedentes de los pacientes

\begin{tabular}{cc}
\hline$N^{\circ}$ de cirugías abdominales previas: & $\mathrm{n}=100$ \\
1 & 67 \\
2 & 22 \\
3 & 8 \\
4 & 3 \\
Tipo de cirugía abdominal previa*: & $\mathrm{n}=100$ \\
1. Colon y recto & 20 \\
2. Ginecológica & 18 \\
3. Apendicectomía & 17 \\
4. Gástrico & 15 \\
5. Vías biliares & 11 \\
6. Otras & 19
\end{tabular}

Ingresos previos por obstrucción adherencial (Sí / No)

$29 / 71$

Tiempo medio desde el último ingreso al actual (rango) 2 años $(0,5-40)$

Cirugía en el ingreso previo (Sí / No)

$6 / 23(20 \% / 80 \%)$

Tipo de cirugía en el ingreso previo:

1. Adhesiolisis

2. Resección intestinal

4

2

* Se considera sólo la primera cirugía de todos los pacientes.

\section{Tabla II. Cuadro clínico actual}

\begin{tabular}{lr}
\hline Manifestaciones clínicas: & 77 \\
Vómitos & 52 \\
Estreñimiento & $68 / 12$ \\
Dolor abdominal leve-moderado (cólico / continuo) & $46 / 34$ \\
Localización del dolor (localizado / difuso) & 56 \\
Distensión abdominal &
\end{tabular}

Tiempo medio de evolución ( \pm desviación estándar)

$2,1 \pm 2$ días

\begin{tabular}{l} 
Datos complementarios*: \\
Fiebre \\
Leucocitosis \\
Taquicardia (FC)** \\
Radiología al ingreso: \\
Obstrucción parcial \\
Obstrucción completa \\
\hline * (media en caso de que "Sí \\
** FC: frecuencia cardiaca en latidos por minuto
\end{tabular}

de media del ingreso (mínimo: 6 horas, máximo: 72 horas), mientras que en los 5 restantes se inició tolerancia por mejoría, siendo esta efectiva. El valor mínimo de 6 horas resultó ser un paciente que presentó aumento claro del dolor abdominal, indicándose, por tanto, la cirugía sin esperar a completar el protocolo. Los hallazgos y técnicas quirúrgicas se describen en la tabla III. No se encontraron, en ningún caso, asas perforadas con contaminación de la cavidad peritoneal por el contraste baritado, y la presencia del mismo no supuso una dificultad técnica adicional en los casos de resección intestinal. Apuntar que el caso en el que se halló intraoperatoriamente una is-
Tabla III. Hallazgos y técnicas quirúrgicas

\begin{tabular}{lr}
\hline Hallazgos quirúrgicos & $\mathrm{n}=25$ \\
Cuadro adherencial aislado & 11 \\
Hernia interna & 9 \\
Vólvulo intestinal & 3 \\
Neoplasia & 1 \\
Isquemia intestinal & 1 \\
Estrangulación & 8 \\
& \\
Técnicas quirúrgicas & \\
Adhesiolisis & 21 \\
Resección intestinal & 8 \\
Devolvulación & 3 \\
Ostomía & 1 \\
Laparostomía & 1 \\
\hline
\end{tabular}

quemia intestinal, resultó ser de origen trombótico, siendo, sin embargo, diagnosticada de inicio como OIA. Cinco pacientes presentaron complicaciones postoperatorias (20\%), destacando 3 infecciones de herida, una infección de orina y un íleo paralítico. Un paciente falleció al $4^{\circ}$ día postoperatorio, debido a una insuficiencia cardiaca congestiva (mortalidad postoperatoria del $4 \%$, y del $1 \%$ en la serie global).

El tiempo medio total de estancia desde el ingreso en el Servicio de Urgencias de los 30 pacientes sin evidencia de contraste en colon fue de 13,8 \pm 11 días (intervalo de 5- 55 días).

Dentro de los cuadros radiológicos iniciales -radiografía simple de abdomen- de obstrucción completa (25 pacientes), 17 fueron tratados de forma conservadora (68\%), mientras que 8 lo fueron quirúrgicamente (32\%). Del total de cuadros de obstrucción parcial (75 pacientes), 58 fueron tratados de manera conservadora (77\%), y los 17 restantes quirúrgicamente $(23 \%)$.

La sensibilidad, especificidad, valor predictivo positivo y negativo, así como el valor global de la prueba, determinados por el paso de contraste a colon derecho en las primeras 24 horas como indicador de necesidad de cirugía del cuadro fue respectivamente de 93, 96, 98, 83 y 94\% siendo representados con sus respectivos intervalos de confianza en la tabla IV.

En 15 casos el contraste no apareció en ninguna de las radiografías realizadas, siendo todos ellos subsidiarios de cirugía ya que no presentaron mejoría clínico-radiológica del cuadro.

En cuanto al estudio estadístico, se demuestra significación estadística para la positividad de contraste en colon derecho en relación con la tolerancia efectiva a la dieta líquida, de la misma forma que la negatividad se asocia con la necesidad de cirugía, para una $\mathrm{p}<0,01$. Para la posible identificación de alguna variable predictora de la positividad de la prueba, únicamente la variable "número de cirugías previas" tiende a la significación estadística para una $\mathrm{p}=0,07$, siendo más probable la tolerancia posi- 
Tabla IV. Ausencia de contraste a colon derecho como indicador de necesidad de cirugía

\begin{tabular}{lcc}
\hline Sensibilidad & $93,24 \%$ & $(84,27-97,49)$ \\
Especificidad & $96,15 \%$ & $(78,41-99,80)$ \\
Valor predictivo positivo & $98,57 \%$ & $(91,23-99,23)$ \\
Valor predictivo negativo & $83,33 \%$ & $(64,54-93,70)$ \\
Valor global de la prueba & $94 \%$ & $(86,88-97,54)$ \\
\hline
\end{tabular}

Entre paréntesis se sitúan los intervalos de confianza de los valores para el 95\%

tiva si el paciente presenta más de una cirugía abdominal previa (variable de agrupación: "tolerancia efectiva").

\section{DISCUSIÓN}

La obstrucción intestinal de causa adherencial es una urgencia quirúrgica frecuente cuyo manejo global permanece aún controvertido. A pesar de que en ausencia de signos de abdomen agudo por sospecha de estrangulación el tratamiento conservador se indica de manera rutinaria, la duración de este tratamiento conservador es muy variable. En la mayoría de las series se recomienda que el periodo de tratamiento conservador sea, como máximo, de 48 horas $(6,13,14)$, aunque existen suficientes evidencias clínicas de resolución espontánea tras 4 y 5 días de tratamiento conservador.

Los datos demográficos y clínicos de los pacientes de nuestra serie son similares a los de la bibliografía. Tal vez cabe destacar la diferencia que existe en la nuestra con respecto a otras, en relación a los antecedentes personales de ingresos previos por OIA, siendo nuestra incidencia el doble que la de una serie reciente (15).

Es necesario resaltar que sólo algunos pacientes que presentan al ingreso cuadro de OIA refieren dolor abdominal importante, siendo la intensidad de este dolor uno de los elementos fundamentales en la decisión quirúrgica. La presencia de un dolor intenso y continuo, acompañado o no de otros signos, debe hacer sospechar estrangulación, con la consiguiente indicación de cirugía urgente. Sin embargo, una mayoría de pacientes van a tener un cuadro clínico inicial más larvado y benigno, donde predomina la distensión abdominal, sin dolor o con dolor de intensidad leve a moderada.

Los porcentajes de cirugía en los cuadros obstructivos adherenciales suelen oscilar entre el 27 y el $42 \%$, siendo en nuestra serie del $25 \%$. Se apunta que las intervenciones previas del compartimento inframesocólico son las de más riesgo en este sentido (2,15-17).

Existen algunas series que tratan de encontrar mediante el análisis estadístico algún factor predictivo que ayude a elegir el tratamiento óptimo en cada caso. Así, Escrig VJ y cols., indican que la ausencia de aireación del colon, la alteración del ionograma, y la localización inframesocólica de la cirugía previa presentan un valor predictivo independiente a la hora de indicar la cirugía (15). En nuestra serie, únicamente el mayor número de cirugías abdominales previas parece indicar la posibilidad de una menor necesidad de cirugía del cuadro adherencial. La obstrucción completa radiológica inicial, reflejada en la ausencia de aireación del colon, no resultó predictiva de ausencia de contraste en colon, y por tanto, de posible indicación quirúrgica. Entre los que presentaron en nuestra serie contraste en el colon, el $22 \%$ presentaban inicialmente radiología de obstrucción completa, mientras que entre los que no lo presentaban, el $32 \%$ presentaban dicha radiología. Por tanto, en nuestra serie una radiología inicial de obstrucción completa no fue predictiva desde un principio de un manejo quirúrgico de la OIA, en cuyo caso haría innecesario el protocolo aquí empleado. Otras publicaciones indican el débito a través de la sonda nasogástrica así como el grado de dilatación de asas de intestino delgado como indicadores de necesidad de cirugía (7). Sin embargo, es importante destacar que, en definitiva, aún no se han determinado con claridad los factores de riesgo sobre el fracaso del tratamiento conservador en este tipo de obstrucciones.

La utilización de contraste hidrosoluble ha sido evaluada recientemente con el fin de predecir la necesidad de cirugía en la obstrucción adherencial de intestino delgado. El posible valor terapéutico de este contraste resulta todavía controvertido. Así, Assalia y cols., señalan en un estudio aleatorizado que el contraste hidrosoluble adelanta significativamente la resolución del problema, acortando por tanto la estancia hospitalaria y la necesidad de cirugía en un $10 \%$ (6). Por el contrario, Feigin y cols., y Fevang y cols. no refieren ventaja alguna $(11,12)$. El Gastrografín ${ }^{\mathrm{TM}}$ es el contraste hidrosoluble más empleado.

Chen y cols. estudian el papel predictivo de este contraste hidrosoluble en el manejo de las obstrucciones adherenciales (5). En su serie, los pacientes con contraste en colon derecho dentro de las primeras 24 horas fueron tratados con éxito en el $100 \%$ de los casos mediante tratamiento conservador. La cirugía fue necesaria en el $96 \%$ de los pacientes en cuyo colon derecho no aparecía contraste en las primeras 24 horas. Nuestro estudio confirma los resultados obtenidos por Chen et al, aunque con contraste baritado diluido (5). Tan sólo el valor predictivo negativo de la prueba resulta menor, por lo que existen pacientes sin contraste en el colon derecho que no han requerido cirugía.

La concentración del contraste baritado al 5\%, determinada por el Departamento de Radiología, evitaba teóricamente el riesgo de complicaciones, y se estimó como la mínima concentración capaz de permitir una visualización aceptable del contraste en la luz intestinal. Sin embargo, con el empleo del contraste baritado se obviaban las propiedades osmóticas que sí posee el Gastrografín ${ }^{\mathrm{TM}}$, y que pueden colaborar en la resolución del cuadro. Un segundo aspecto importante en nuestros resultados es la ausencia total de contraste -en intestino delgado o grueso- en las radiografías en 15 pacientes a lo largo de la realización del protocolo. Todos ellos fueron subsidiarios posteriormente de cirugía por no mejorar el cuadro por el 
que ingresaron en el Servicio de Urgencias. Creemos que la explicación más probable es que debido a la importante distensión de asas que presentaban estos pacientes, y la consiguiente acumulación de aire y secreciones, el contraste se diluye de tal modo que no se aprecia en ninguna de las radiografías. Es lógico concluir que con este grado de obstrucción en ninguno de estos casos se produjera mejoría, requiriendo todos ellos una intervención quirúrgica.

La estancia hospitalaria de los pacientes que finalmente no van a requerir cirugía puede verse reducida gracias a este protocolo, y en nuestra serie se muestra una estancia media en urgencias de 43 horas \pm 17 horas. En series recientes se refiere una estancia media de 6 días para los que recibieron tratamiento conservador, siendo similar a la de los pacientes intervenidos (15). Si nuestros resultados se confirmaran por otros grupos este protocolo podría reducir el tiempo de indicación quirúrgica y de manejo conservador de la OIA, pues en 24 horas como máximo desde la ingesta del contraste se puede decidir una de las opciones, según la presencia o ausencia de contraste en el colon y la mejoría clínico-radiológica del paciente. Este menor tiempo de manejo conservador y la más precoz indicación quirúrgica podrían también disminuir el porcentaje de resecciones intestinales y la morbilidad consecuente.

Como conclusión, el uso precoz del contraste radiológico (bario diluido) en pacientes que presentan obstrucción intestinal de causa adherencial puede predecir de una manera más eficaz y precoz la necesidad de cirugía, con la consecuente disminución de estancia hospitalaria y potencial morbilidad de una cirugía tardía.

\section{AGRADECIMIENTOS}

A la Unidad de Investigación de nuestro centro, por su colaboración en el análisis estadístico de este trabajo. 